
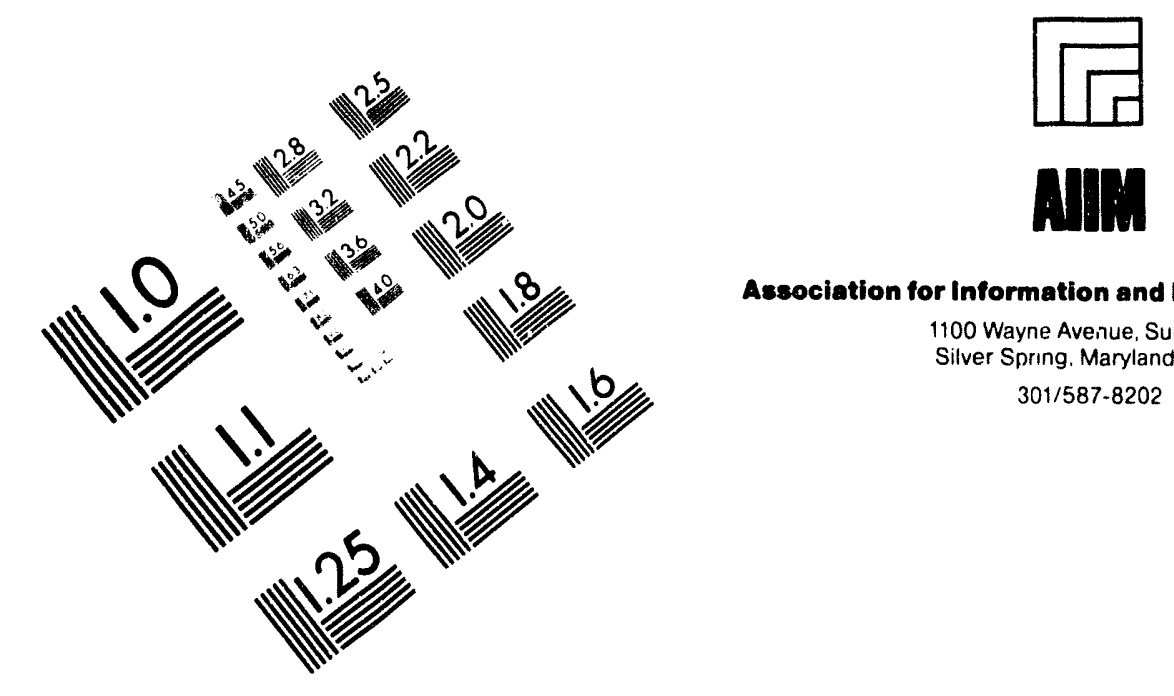

Association for Information and Image Management

1100 Wayne Avenue, Suite 1100

Silver Spring. Maryland 20910

$301 / 587-8202$

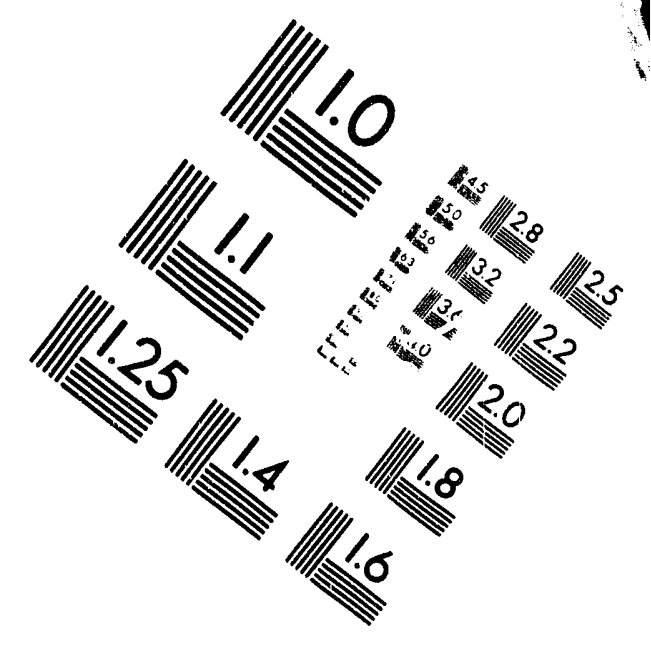

Centimeter

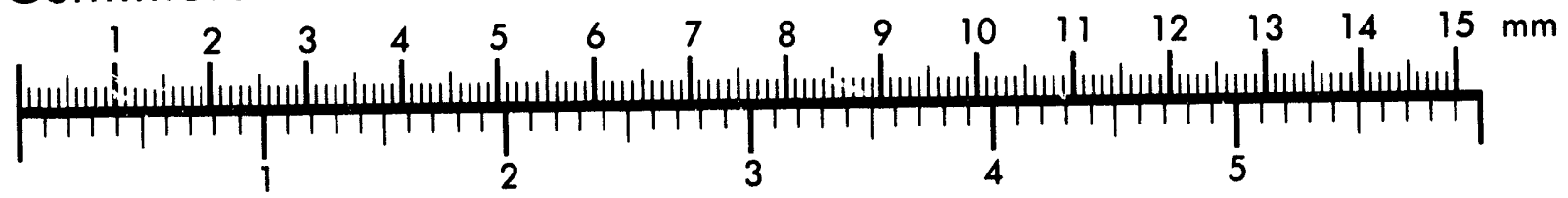
Inches

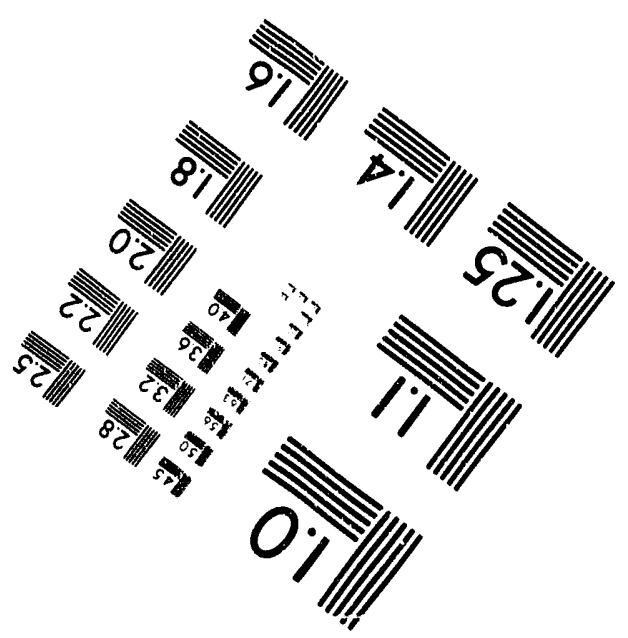

MANUFACTURED TO AIIM STANDARDS

BY APPLIED IMAGE, INC.

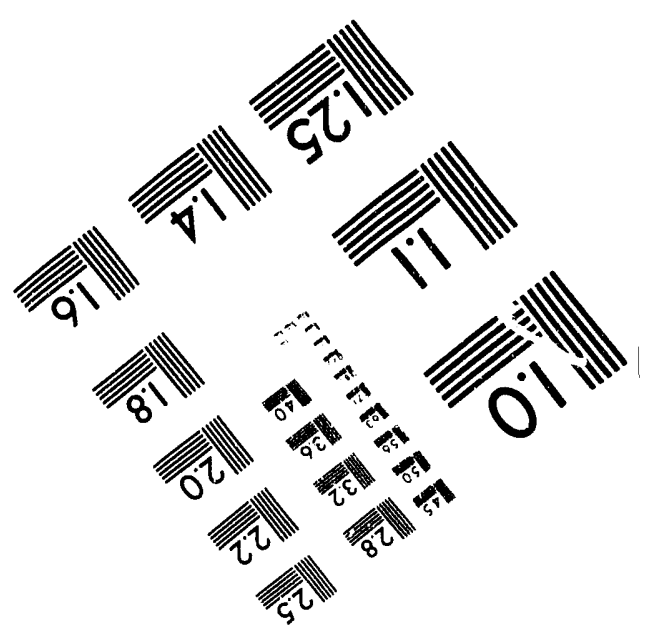



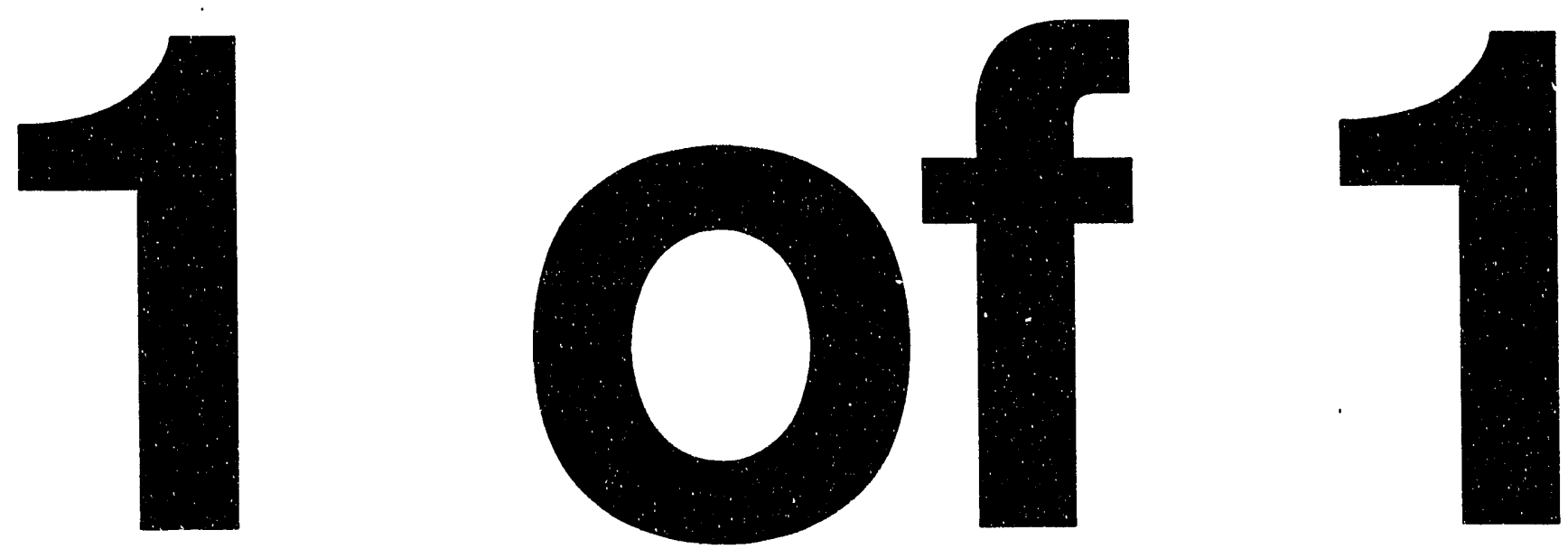


\section{PULSED LASER KINETIC STUDIES OF LIQUIDS UNDER HIGH PRESSURE}

Final Technical Report

for Period April 1, 1990 - March 31, 1993

Edward M. Eyring

University of Utah

Salt Lake City, UT 84112

June 21, 1993

Prepared for

THE U.S. DEPARTMENT OF ENERGY

AGREEMENT NO. DE-FGO2-84ER $1: \angle 27$

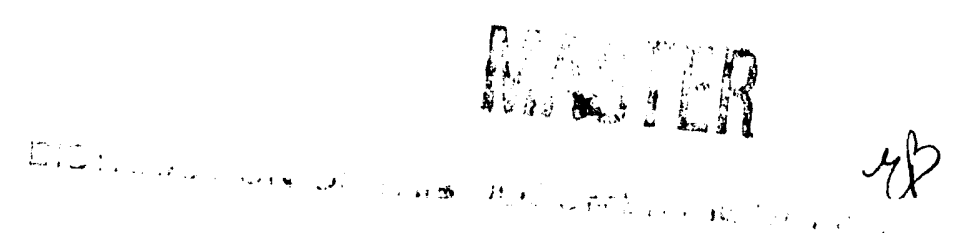




\section{Pulsed Laser Kinetic Studies of Liquids Under High Pressure}

Final Technical Report Abstract

Several different experiments have been developed for measuring the rates of chemical reactions in liquids and in supercritical $\mathrm{CO}_{2}$. A pulsed (Q-switch) $\mathrm{Nd}$ :YAG laser operated at $\lambda=355 \mathrm{~nm}$ has been the pump beam for laser flash photolysis studies of molybdenum and tungsten hexacarbonyls undergoing ligand displacement reactions by bidentate chelating agents such as 2,2'-bipyridine in the solvent toluene. Experiments were carried out at pressures ranging from 0.1 to $150 \mathrm{MPa}$. In the case of molybdenum complexes the reaction mechanism for thermal ring closure is found from activation volumes to change from associative interchange to dissociative interchange as substituents on the 2,2' -bipyridine ligands become bulkier. In a similar study of more rigid, substituted phenanthroline bidentate ligands it was found that substituent bulkiness had little effect on the thermal ring closure mechanism. Similar high pressure flash photolysis experiments with tungsten hexacarbonyl have also been completed. The concentration dependence of the fluorescence and nonradiative decay quantum yields for cresyl violet in several solvent have been reported as well as stability constants for the complexation of lithium ion by four different crown ethers dissolved in a room temperature molten salt.

\section{N O}

This report was prepared as an account of work sponsored by the United States Government. Neither the United States nor the Department of Energy, nor any of their contractors, subcontractors, or their employees, makes any warranty, express or implied, or assumes any legal liability or responsibility for the accuracy, completeness, or usefulness of any information, apparatus, product or process disclosed or represents that its use would not infringe privately-owned rights. 
Pulsed Laser Kinetic Studies of Liquids Under High Pressures

The principal investigator (P.I.) spent a week in the laboratory of Professor Rudi van Eldik in Witten, Germany in May, 1990. A high pressure stainless steel sample cell with three quartz windows had been built in Professor van Eldik's $l \mathrm{ab}$ and was brought back to the University of Utah by the P.I. at that time. With the help of Dr. K. Bal Reddy, who had previously spent a year and a half as a postdoctoral research associate in Professor van Eldik's lab, a high-pressure laser flash photolysis experiment was set up at Utah. This experiment takes advantage of the availability of a Quanta Ray DCR-2 Nd:YAG laser that had been in the P.I.'s laboratory for nearly a decade. The resulting experimental set-up is shown in Fig. 1. The pulsed frequency tripled $(\lambda=355 \mathrm{~nm})$ ultraviolet output ( $100 \mathrm{~mJ}, 6 \mathrm{~ns}$ fwhi) from the Nd:YAG laser serves as the pump beam in these flash photolysis experiments. The visible wavelength probe beam from a $75 \mathrm{~W}$ xenon arc lamp passes through a monochromator, then through the high pressure sample cell, and finally reaches a 1P28 photomultiplier tube (PMT) detector. The pump and probe beams cross through the quartz pillbox sample cell at right angles to one another. The pillbox cell sits inside the high-pressure stainless steel autoclave and is immersed in liquid heptane that transmits pressures ranging up to $1.50 \mathrm{MPa}$ generated by a mechanical hydraulic pump. The high pressure cell is thermostatted $\left( \pm 0.1^{\circ} \mathrm{C}\right)$ by water circulating through copper tubing soldered around the outside of the high-pressure autoclave. The optical path length of the probe beam through the pillbox sample cell is approximately $15 \mathrm{~mm}$. Sample solutions are introduced into the pillbox cell with a special filling system ${ }^{2}$ that excludes moisture and prevents the formation of gas bubbles. The voltage transient from the PMT is passed to a LeCroy 9400 oscilloscope and thence to an IBM-compatible PC for analysis with computer programs developed in-house. First order rate constants are calculated from averages of 5 to 10 kinetic traces. Volumes of activation $\Delta \mathrm{V}^{*}$ are calculated from the slopes $\left(-\Delta \mathrm{V}^{*} / \mathrm{RT}\right)$ of plots of $\ln k_{\text {obs }}$ versus the pressure $P$.

It has long been known that photolysis of $M(C O)_{6}$ complexes, where $M=$ $\mathrm{Cr}$, Mo or $\mathrm{W}$, in the presence of a ligand $\mathrm{L}$ produces $\mathrm{M}(\mathrm{CO})_{5} \mathrm{~L}$. When $\mathrm{L}$ is a bidentate ligand a subsequent thermal ring-closure reaction yields $M(C O)_{4} L$. 


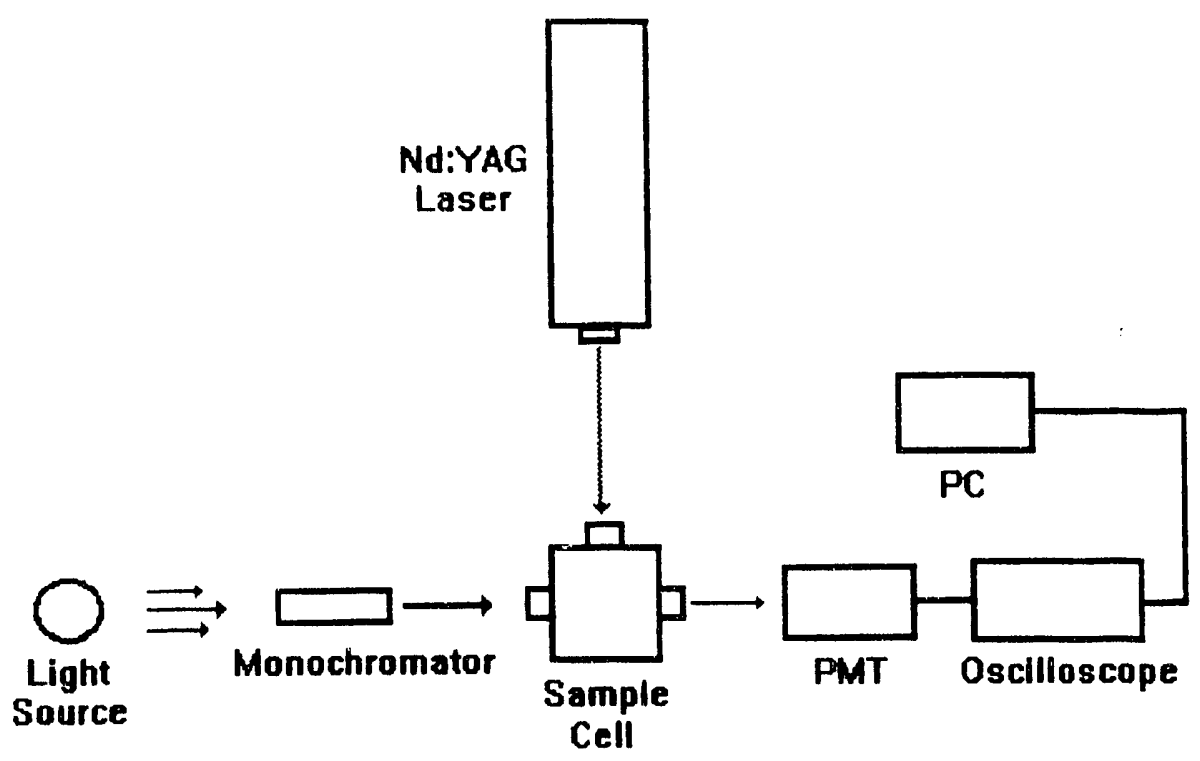

Fig. 1. A laser flash photolysis apparatus for making rate measurements in liquids at elevated pressures. PMT denotes a photomultiplier tube and PC denotes an IBM PC compatible microcomputer.

The reaction mechanism can be written as

$$
\begin{aligned}
& \mathrm{M}(\mathrm{CO})_{6} \stackrel{\mathrm{h} \nu}{\rightarrow} \mathrm{M}(\mathrm{CO})_{5}+\mathrm{CO} \\
& \mathrm{M}(\mathrm{CO})_{5}+\text { solv } \stackrel{\text { fast }}{\rightarrow} \mathrm{M}(\mathrm{CO})_{5} \mathrm{solv} \\
& \mathrm{M}(\mathrm{CO})_{5} \text { solv }+\mathrm{L} \stackrel{\mathrm{k}_{1}}{\rightarrow} \mathrm{M}(\mathrm{CO})_{5} \mathrm{~L}+\operatorname{solv} \\
& \mathrm{M}(\mathrm{CO})_{5} \mathrm{~L} \stackrel{\mathrm{k}_{2}}{\rightarrow} \mathrm{M}(\mathrm{CO})_{4} \mathrm{~L}+\mathrm{CO}
\end{aligned}
$$

In this mechanism a solvent molecule is denoted by solv.

Laser flash photolysis kinetic studies ${ }^{3}$ of the reaction of $M o(C O)_{6}$ with the bidentate 1igands 2,2'-bipyridine (bpy), 4,4'-dimethyl-2,2'-bipyridine (dmbpy) and 4,4'-dipheny1-2,2'-bipyridine (dpbpy) in the solvent toluene yielded activation volumes for ring closure ranging from -7.0 to $+4.7 \mathrm{~cm}^{3}$ 
mol $^{-1}$. The low oxidation states of these complexes and the use of neutral ligands simplify the interpretation of the observed pressure effects, since these effects can, in the absence of major solvational changes, be associated with intrinsic volume changes arising from changes in bond lengths and bond angles during the substitution process. From the volume of activation data we inferred that the reaction mechanism changes from associative interchange ( $I_{a}$ ) to dissociative interchange $\left(I_{d}\right)$ because of increasing steric hindrance as the iigand L becomes bulkier.

When the more rigid, bidentate phenanthroline ligands (5-chloro-1,10phenanthroline, 2,9-dimethyl-1,10-phenanthroline, 4,7-dimethyl-1,10phenanthroline, 3,4,7,8-tetramethyl-1,10-phenanthroline, and 4,7-diphenyl1,10-phenanthroline) were reacted with $\mathrm{Mo}(\mathrm{CO})_{6}$ in high pressure, laser flash photolysis experiments ${ }^{4}$ it was found that the phenanthroline ligands have less impact on the thermal ring closure mechanism than had previously been noted ${ }^{3}$ with the flexible bipyridine ligands. The ring closure of these rigid phenanthroline chelates goes by an interchange (I) mechanism in which bond formation and bond cleavage at the Mo center occur to a similar degree in the transition state independent of the size of the substituent groups on the phenanthroline chelate. ${ }^{4}$

Another related question is whether changing the size of the Mo metal center to a smaller $\mathrm{Cr}$ metal center or a larger $\mathrm{W}$ metal center will have a major impact on the mechanism of thermal ring closure. A laser flash photolysis study 5 of the kinetics of thermal ring closure involving the tungsten carbonyl complex, $W(\mathrm{CO})_{5} L$, where L denotes 2,2'-bipyridine(bpy), 4,4' -dimethyl-2,2' -bipyridine(dmbpy), 4,4'-diphenylbipyridine(dpbpy), and 4,4'-di-tert-butyl-2,2'-bipyridine(d-Bubpy) was carried out in toluene. Some 
of the as yet unpublished results ${ }^{5}$ are shown in Table I. These kinetic data show that the rate of ring-closure of $\mathrm{W}(\mathrm{CO})_{5} \mathrm{~L}$ complexes follows the order bpy>dmbpy>dpbpy, in agreement with an earlier study in a different solvent, benzene. An increase in steric hindrance on the chelating ligand does significantly affect the rate of ring closure. The $\Delta \mathrm{V}^{*}$ values strongly suggest a changeover in mechanism from $I_{a}$ to $I_{d}$ on increasing the steric hindrance on the bpy ligand. The introduction of two methyl substituents causes an increase in $\Delta V^{*}$ of almost $6 \mathrm{~cm}^{3} \mathrm{~mol}^{-1}$, whereas the introduction of two phenyl substituents causes an increase in $\Delta V^{*}$ of almost $12 \mathrm{~cm}^{3} \mathrm{~mol}^{-1}$. The small absolute magnitude of $\Delta \mathrm{V}^{*}$ is in good agreement with that typically found for interchange processes.? The positive $\Delta \mathrm{V}^{*}$ value observed for $L=$ dpbpy must arise as a result of more $\mathrm{W}$-CO bond lengthening during the formation of the transition state due to steric congestion caused by the bulky phenyl substituent. Such a changeover in mechanism was also observed for thermal ring-closure reaction of $\mathrm{Mo}(\mathrm{CO})_{5} \mathrm{~L}$ complexes when the $\mathrm{L}$ is changed from bpy to dpbpy. ${ }^{3}$ Thus the size of the metal center and the size of the coordinated and entering ligands both play a crucial role in determining the location of the transition state along the reaction coordinate which involves bond cleavage with the leaving group and bond formation with the entering nucleophile.

Since the sample systems considered in these laser flash photolysis experiments involve uncharged reactants and uncharged reaction products, these reactions lend themselves to rate studies in other low relative permittivity solvents such as supercritical carbon dioxide. A syringe pump, home-made controller, and an old Apple computer were borrowed from Prof. Milton Lee (B.Y.U.) and another high pressure autoclave with three quartz windows was built in the University of Utah shops for laser flash photolysis kinetic 
Table I. Rate Constants and Activation Volumes for Chelate Ring Closure in $\mathrm{W}(\mathrm{CO})_{5} \mathrm{~L}$ Complexes in Toluene. ${ }^{5}$

\begin{tabular}{|c|c|c|c|c|}
\hline $\mathrm{L}$ & $\begin{array}{l}\mathrm{T} \\
{ }^{\circ} \mathrm{C}\end{array}$ & $\begin{array}{l}\mathrm{P} \\
\mathrm{MPa}\end{array}$ & $\begin{array}{l}k_{\text {obs }} \\
s^{-1}\end{array}$ & $\begin{array}{c}\Delta \mathrm{V}^{*} \\
\mathrm{~cm}^{3} \mathrm{~mol}^{-1}\end{array}$ \\
\hline \multirow[t]{5}{*}{ bpy } & 25.0 & 5 & $0.080 \pm 0.002$ & $-10.9 \pm 1.1$ \\
\hline & & 25 & $0.091 \pm 0.003$ & \\
\hline & & 50 & $0.105 \pm 0.003$ & \\
\hline & & 75 & $0.113 \pm 0.002$ & \\
\hline & & 100 & $0.122 \pm 0.004$ & \\
\hline \multirow[t]{4}{*}{ dmbpy } & 40.0 & 0.1 & $0.139 \pm 0.014$ & $-5.4 \pm 0.61$ \\
\hline & & 50 & $0.158 \pm 0.014$ & \\
\hline & & 100 & $0.179 \pm 0.017$ & \\
\hline & & 150 & $0.190 \pm 0.012$ & \\
\hline \multirow[t]{4}{*}{ dpbpy } & 40.0 & 0.1 & $0.136 \pm 0.024$ & $0.60 \pm 0.07$ \\
\hline & & 50 & $0.134 \pm 0.010$ & \\
\hline & & 100 & $0.132 \pm 0.009$ & \\
\hline & & 150 & $0.131 \pm 0.011$ & \\
\hline
\end{tabular}

studies of $\mathrm{Mo}(\mathrm{CO})_{6}$ in supercritical $\mathrm{CO}_{2}$. A quartz pill box sample cell is not suitable for the supercritical fluid (SF) experiments. We now use a small sample cuvette, sealed with a plastic plug through which a long $(20 \mathrm{~cm})$ piece of $0.5 \mathrm{~mm}$ I.D. plastiec tubing extends. This tubing permits the entrance and escape of $\mathrm{CO}_{2}$ from the sample cuvette without the loss of either $\mathrm{Mo}(\mathrm{CO})_{6}$ or bidentate ligand from the cuvette. Reproduciblilty of the kinetic traces is thus greatly improved.

A high pressure stopped-flow spectrophotometer was constructed in the University of Utah shops just before the termination of this contract on March 31, 1993. It permits the extension of the above described laser flash photolysis kinetic experiments to a longer time scale. (In the month of 
April, 1993, the high pressure stopped-flow spectrophotometer was used to complete a kinetic study of the complexation of gadolinium(III) ion by EDTA in aqueous solution.)

Several other research problems were addressed during the three year contract period that did not involve the use of high pressure instrumentation. Aluminum chloride combined with one of a number of quaternary ammonium chloride salts forms an ionic liquid at room temperature. ${ }^{7} \mathrm{Li}-\mathrm{NMR}$ data were gathered on the complexation of $\mathrm{Li}^{+}$by four different simple crown ethers [12crown-4, 15-crown-5, benzo-15-crown-5 and 18-crown-6] in one of these room temperature, molten salts. A computer program was developed in-house for deducing equilibrium constants from the NMR data. The most stable $1: 1$ complex ion was found ${ }^{8}$ to form from $\mathrm{Li}^{+}$and 15-crown-5. This combination provides the best size fit of the crown ether 1 igand cavity ( $0.85 \AA$ radius) to the lithium ion ( $0.74 \AA$ radius). Preparation of the ultra dry aluminum chloride for the molten salt is somewhat hazardous and the mixing of the many molten salt NMR samples in a Vacuum Atmospheres glove box proved to be very tedious. Should renewed interest develop in the room temperature molten salts as battery electrolytes it would perhaps be practical to lower the internal electrical resistance of such a battery by adding a crown ether to the electrolyte mixture.

Dr. Stefan Isak completed a very thorough Ph.D. thesis ${ }^{9}$ that describes his photothermal beam deflection studies of several dyes dissolved in liquids. An interesting insight from these studies is that the workhorse for gathering relative fluorescence quantum yields (using cresyl violet in methanol as a standard) was a Perkin-Elmer MPF-66 fluorescence spectrophotometer that represents pre-laser technology. However, the complete story ${ }^{9}$ could not have 
been told without the absolute fluorescence quantum yield dependence on concentration of cresyl violet in methanol ${ }^{10}$ obtained with a pulsed, wavelength tunable dye laser (pumped by a frequency doubled Nd:YAG laser) in Isak's photothermal beam deflection experiment.

A rate study ${ }^{11}$ of the oxidation of alcohols by $\mathrm{OsO}_{4}$ in alkaline aqueous solutions was carried out on a Hewlett-Packard 8452A diode array UV-VIS spectrophotometer. These slow reactions yield evidence from Hammett plots and kinetic isotope effects for a hydride ion transfer reaction mechanism.

Two publications ${ }^{12,13}$ were prepared that describe the use of microphonic photoacoustic detection in X-ray absorption experiments. This research was done at two synchrotrons in Japan and at the Brookhaven National Laboratory. 


\section{$\underline{\text { References }}$}

1. le Noble, W.; Schlott, R. Rev. Sci. Instrum. 1976, 47, 770.

2. Wieland, S.; van Eldik, R. Rev. Sci. Instrum. 1989, 60, 955.

3. Reddy, K.B.; Hoffmann, R.; Konya, G.; van Eldik, R.; Eyring, E.M. Organometallics 1992, 11, 2319.

4. Reddy, K.B.; Brady, B.R.; Eyring, E.M.; van Eldik, R. J. Organometallic Chem. 1992, 440, 113.

5. Cao, S.; Reddy, K.B.; Eyring, E.M.; van Eldik, R., in preparation.

6. Schadt, M.J.; Lees, A.J. Inorg. Chem. 1986, 25, 672 .

7. van Eldik, R.; Asano, T.; le Noble, W. Chem. Rev. 1989, 89, 549.

8. Eyring, E.M.; Cobranchi, D.P.; Garland, B.A.; Gerhard, A. ; Highley, A.M.; Huang, Y.-H.; Konya, G.; Petrucci, S.; van Eldik, R. Pure \& Appl. Chem. $1993, \underline{65}, 451$.

9. Isak, S.J. Applications of Photacoustic. Photothermal and Fluorescence Spectroscopies in Signal Enhancement and the Kinetics. Chemistry and Photophysics of Several Dyes, Ph.D. Dissertation, University of Utah, Salt Lake City, UT, June, 1992.

10. Isak, S.J.; Eyring, E.M. J. Phys. Chem. 1992, 96, 1738.

11. Ku, J.; Cao, S.; Reddy, K.B.; Eyring, E.M., in preparation.

12. Isak, S.J.; Garland, B.A.; Eyring, E.M.; Kirkland, J.P.; Neiser, R.A. App1. Phys. B 1991, 52, 8.

13. Masujima, T.; Eyring, E.M. in Progress in Photothermal and Photoacoustic Science and Technology, Vol. 2, Nondestructive Evaluation (NDE), A. Mandelis, Ed., Elsevier Science Publishing Co., New York, submitted for publication. 
Personnel

Persons paid from this grant during its three year duration include (in alphabetical order): $R$. Bryan Brady, undergraduate student recently admitted to medical school; Shibai Cao, graduate student; Edward M. Eyring, principal investigator; Ben Garland, former graduate student now employed by Nicolet in California; Achim Gerhard, postdoctoral research associate now in Germany; Aaron Highley, Yale undergraduate chemistry major; Rudiger Hoffmann, visiting graduate student who recently received his $\mathrm{Ph} . \mathrm{D}$. in Germany; Stefan J. Isak, former graduate student now employed by Sandoz in New Jersey; Qin Ji, graduate student; Bernice Kickel, graduate student; Gabor Konya, graduate student; $\mathrm{K}$. Bal Reddy, postdoctoral research associate now at Rutgers University in New Jersey; Barbara Staker, draftsman; Paul Thompson, postdoctoral research associate now teaching at a junior college; Rudi van Eldik, consultant; and H. Paul Wang, postdoctoral research associate now an associace professor in Taiwan. 
Publications Acknowledging Support of this Grant Since April 1, 1990

1. E.M. Eyring, S.J. Komorowski, N.F. Leite, and T. Masujima, "Photoacoustic Instrumentation," in Analytical Instrumentation Handbook, G. W. Ewing, Editor, Marcel Dekker, New York, 1990, Chapter 10, pp. 337360 .

2. D. P. Cobranchi, N. F. Leite, J. Isak, S. J. Komorowski, A. Gerhard and E. M. Eyring, "Pulsed Laser Photothermal Radiometry and Photothermal Beam Deflection Spectroscopy: Determination of Thermal Diffusivities of Liquids," in Photoacoustic and Photothermal Phenomena II (Springer Series in Optical Sciences Vol. 62), J. C. Murphy, J. W. Maclachlan Spicer, L. C. Aamodt, and B. S. H. Kuyce, Editors, Springer-Verlag, New York, 1990, pp. 328-330.

3. S. J. Isak, B. A. Garland, E. M. Eyring, J. P. Kirkland and

R. A. Neiser, "Photoacoustic Signal Enhancement at Visible and X-ray Wavelengths", Appl. Phys. B, $\underline{52}, 8-13$ (1991).

4. S. J. Isak and E. M. Eyring, "Fluorescence Quantum Yield of Cresyl Violet in Methanol and Water as a Function of Concentration, " J. Phys. Chem., 96, 1738-1742 (1992).

5. S. J. Isak and E. M. Eyring, "Cresyl Violet Chemistry and Photophysics in Various Solvents and Micelles," J. Photochem. \& Photobiol. A:Chem., 64, 343-358 (1992).

6. K. B. Reddy, R. Hoffmann, G. Konya, R. van Eldik and E. M. Eyrir.g, "Thermal Ring Closure in Mo(CO) ${ }_{5} L$ ( $L=$ bpy, dmbpy, dpbpy) Trarsients Generated by Pulsed Laser Flash Photolysis. Mechanistic Information from High Pressure Effects," Organometallics, 11, 2319-2322 (1992).

7. K. B. Reddy, B.R. Brady, E.M. Eyring and R. van Eldik, "Effect of Pressure on Intramolecular Ring-Closure Reactions of Molybdenum Carbonyl Complexes Induced by Flash Photolysis," J. Organometallic Chem., 440, 113-117 (1992).

8. S.J. Isak, Application of Photoacoustic, Photothermal and Fluorescence Spectroscopies in Signal Enhancement and the Kinetics, Chemistry and Photophysics of Several Dyes, Ph.D. Dissertation, University of Utah, Salt Lake City, June, 1992.

9. E.M. Eyring, D.P. Cobranchi, B.A. Garland, A. Gerhard, A.M. Highley, Y.H. Huang, G. Konya, S. Petrucci and R. van Eldik, "Lithium Ion-Crown Ether Complexes in a Molten Salt," Pure \& App1. Chem., 65, 'f51-454 (1993).

10. S. J. Isak and E. M. Eyring, "Low Fluorescence Quantum Yields of Several Potential Photothermal Sensitizing Direct Blue Dyes," J. Photochem. \& Photobiol. Biology Section, accepted for publication subject to minor revisions. 
13

11. T. Masujima and E.M. Eyring, "X-Ray Thermal NDE," in Progress in Photothermal and Photoacoustic Science and Technology, Vol. II, Nondestructive Evaluation (NDE), A. Mandelis, Ed., Elsevier Science Publishing Co., New York, submitted for publication.

12. J. Xu, S. Gao, K.B. Reddy and E.M. Eyring, "Kinetics of Oxidation of Alcohols by $\mathrm{OSO}_{4}$ in an Aqueous Alkaline Medium: Evidence from Substituent and Kinetic Isotope Effects for a Hydride Ion Transfer Mechanism," in preparation.

13. S. Gao, K.B. Reddy, E.M. Eyring and R. van Eldik, "Mechanistic Study of Thermal Ring Closure in $W(C O)_{5} \mathrm{~L}$ ( $\mathrm{L} \equiv$ by, when and Substituted Analogues) Using a High Pressure, Laser Flash Photolysis Technique," in preparation.

$$
\text { Reprints + Preprints removed }
$$



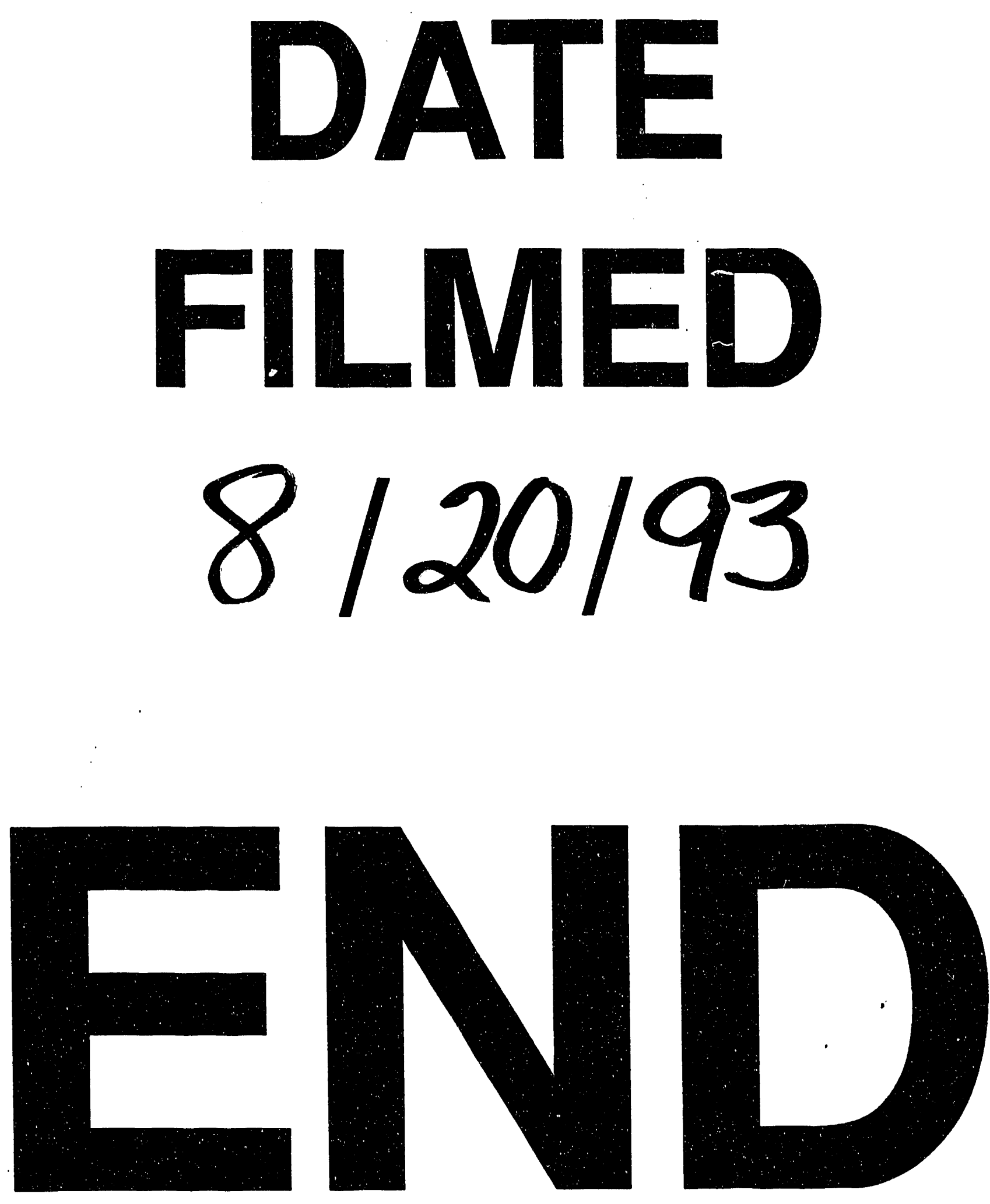
